\title{
FOREST MANAGEMENT ON THE DUCK MOUNTAIN FOREST RESERVE
}

\author{
By George Bedeli \\ Manitoba Forest Service
}

$\mathrm{T}^{\mathrm{H}}$ HE Duck Mountain Forest Reserve is in the western part of the Province of Manitoba. The Duck Mountain, together with the Porcupine Hills, the Riding Mountains and the Pembina Hills, forms a part of the Cretaceous Escarpment but the Cretaceous shales have been covered over by glacial deposits of a later period. The soil is, for the most part, unsuited for agriculture but well adapted to tree growth.

The total area under management is approximately 1,300 square miles. Timber berths were eliminated on account of the impossibility of controlling the amount of the annual cut or the system of cutting. Even on timber berths the brush is being burned and seed trees are being left wherever it is felt that they will be of value. When the merchantable timber has been removed these berths will be cancelled and the area will come under the management plan. The Duck Mountain Experiment Station being under the control of the Dominion Forest Service, was also eliminated. The timber on the remaining area has been used as a local source of supply for settlers in the surrounding country. As settlement gradually extended to the edge of the forest reserve, and settlers became more prosperous, the demand rose until it became apparent that some form of management was necessary.

The shortage of timber first became acute in the Grandview Ranger District, and in 1933 some field work was done with the object of making definite recommendations re the cutting of spruce stands in this area. The work was extended into other ranger districts in 1934, and has developed into the present management plan; the forest reserve being placed on a sustained yield basis (for the spruce working group only) in 1935. The surplus of young age classes in the jack pine working group precludes the possibility of cutting large amounts of this species at the present time and the demand for balsam and hardwoods is extremely limited. It has, therefore, not been necessary to regulate the annual cut of these species but information is available which makes it possible to do this whenever the necessity may arise.

The first part of the management plan is taken up with a brief general description of the working circle as a whole. Ranger districts have, to some extent, been treated as minor working circles as a definite effort is being made to place each district on a sustained yield basis. 
A brief general outline is given for each ranger district, followed by detailed plans for each township (or fraction of a township) which has been cruised. The townships have been treated as compartments, with the indi vidual stands forming the sub-compartments. All stands are numbered, with a separate series of numbers for each ranger district.

A cruise is made of all timber before it is logged. Strips are run at ten chain intervals, and a certain number of increment borings and height measurements are taken. Nine years after cutting, another cruise is to be made of the remaining stand, and a check-up of reproduction, change in growth rate, soil conditions, etc. In this way it should be possible to draw some preliminary conclusions as to the value of different methods of treatment of white and black spruce stands. The first cuttings of any extent of which we have a definite record as to quantity of material removed were made in 1934 and will be re examined in 1943. By that date the pioneer stage of forest management in this area should be definitely over, and rapid advancement should be possible in developing more refined methods of cutting, more accurate methods of estimating increment, etc.

Von Mantel's Formula was used in the first attempt at regulation of the cut. On account of the limited information available at that time, it was the only method which could be used. Rough estimates of spruce sawtimber were made (in feet board measure) from old cruising records and from local knowledge of the area in question. The rotation age was set at 120 years.

At a later date empirical yield tables (based on cruising records) were prepared. By this time the age class distribution tables were more accurate, making it possible to prepare a rough estimate of the annual growth and the cut was limited to the growth on all stands sixty years of age and over.

It is now proposed that the annual cut shall be limited to one-half the total annual increment. No radical change in the cut was caused by these shifts from one method of regulation to another, as the figures obtained were very similar. None of the methods used were found to be entirely satisfactory in all ranger districts and it was necessary, in each case, to modify some of the figures in an arbitrary manner, from local knowledge of the particular ranger district involved. In other words, these formulae are used as a guide but are not rigidly adhered to in all cases in question.

It was not feasible, at the present time, to cut an amount equal to the annual growth, because of the preponderance of the younger age classes. This situation will continue until the timber in the 41.60 age class reaches a size where thinnings can be disposed of as sawtimber.

An annual felling budget is prepared for each ranger district, stating the maximum amount to be cut in the district, the stands in which cutting is to 
take place, the silvicultural treatment of each stand (preparatory cutting, reproduction cutting, or clearcut with seedtrees), the total F.B.M. in the stand, and the F.B.M. to be cut. Comments are added re any errors in marking which have occurred in previous years and have since been checked up.

Local restrictions are sometimes necessary. Settlers' permits are the first consideration, and timber sales are not allowed except where a surplus is available over and above the amount required for local use. In some districts it has been found necessary to limit the maximum amount obtainable by any one permittee, to as small an amount as three or four thousand feet board measure, and in no district does the maximum amount exceed fifty dollars in dues. There was a certain amount of local protest when some of the restrictions were first imposed but it is now generally recognized that the policy adopted is, in the long run, in the best interest of the settlers residing in the district.

Instructions contained in the annual felling budget having been duly carried out, and sawmill records returned, all cutting is reported on an annual cutting report form which is filled in by the ranger in charge of the district. This form gives the stand number, amount of timber which was recommended for removal, and amount actually removed, together with a full explanation of the reason for any excessive undercut or overcut in each individual stand. These figures are then entered on the stock table in the management plan, so that a complete history is available for each stand, dating from the time it was first cruised.

Preparatory cuttings are made in young spruce stands as soon as it becomes economically feasible to do so (fifty to sixty years of age). Defective trees, wolf trees, and trees of poor form are removed but the cut, except in unusually defective stands, is light, as the cutting cycle has been set at ten to twenty years. All of these preparatory cuttings are carried out under authority of settlers' permits. Owing to the small amount removed per acre, there was a certain amount of difficulty at first, in explaining to individual permittees the reason for removing the poorer, instead of the better trees, and for leaving so many trees uncut. This difficulty has been overcome and the policy is now generally accepted by local settlers as being in the best interests of the community.

Stands approaching maturity are cut under the shelterwood system, the stand being removed in three cuts, at ten year intervals. It is too soon to give definite figures as to results obtained, but spruce reproduction is coming in at a satisfactory rate in all stands which have been examined up to date, so that there are certain grounds for believing that it may be possible to obtain spruce reproduction by removing the stand in two instead of in three cuts. 
Mature and overmature spruce is being clear-cut with seed trees. Results have not been entirely satisfactory but it is possible that this is due to insufficient time having elapsed since logging. Where balsam is present, as it usually is in overmature stands, balsam seedlings outnumber the spruce at least thirty to one. This is one of the many problems in this area which require solution in the near future.

Card index records are kept of all increment borings, height and form class measurements, and yield per acre, for each species. Increment borings and height measurements are usually secured when the stand is cruised but form class measurements are made during logging operations. Information is also being collected which may eventually be of some value re site classification. These records are becoming more valuable each year, as more measurements become available.

There are three sets of maps: a map of the forest reserve and surrounding territory, on a scale of three miles to the inch; ranger district maps on a scale of one mile to the inch; and compartment or township maps on a scale of onequarter mile to the inch. The forest reserve map shows roads, phone lines, lookout towers, timber berths, and the larger rivers, creeks and lakes, together with adjacent towns and railway lines. This map is used for location of fires, and in general supervision. The ranger district maps show all the above but in greater detail, and are used in fire-fighting and in laying out forest surveys. The compartment maps contain all information shown on the ranger district maps, in addition to timber type boundaries, and stand numbers. These maps are used in laying out timber sales and cutting areas and in locating individual stands.

In closing, I would like to point out that the above results were obtained without making any elaborate working plan survey of the whole area and with but small additions to the sum which would normally have been spent in cruising timber sales and cutting areas. 